\title{
Preface to Special Column on Progress in Catalysis in China during 1982-2012
}

The Chinese Chemical Society (CCS) has published a book entitled The Boom in Chemistry in China: 1982-2012 to celebrate the 80th anniversary of the CCS. Chapter 28 of the book deals with catalysis. In the past 30 years, much effort has been devoted in China to fundamental and applied research in catalysis, with the following results. A number of domestic and international prizes have been awarded for achievements in catalysis; the quantity and quality of scientific papers have improved significantly; there have been a number of economic and social benefits; many new disciplines have been developed, and significant progress in these has been made. Furthermore, many talented teams with innovative abilities have been formed. China currently deserves to be described as a country which is making significant achievements in catalysis. However, because of space and time limitations, The Boom in Chemistry in China: 1982-2012 does not exhaustively cover China's many major advances in catalysis. This special column has therefore been compiled upon the recommendation of colleagues in catalytic fields.

In catalysis, much attention is focused on research on novel catalytic materials, reactions, and characterization. Novel catalytic reactions developed over the past 30 years include methane aromatization, Fischer-Tropsch synthesis under aqueous conditions, and hydrogenolysis of cellulose and sorbitol to ethylene glycol etc. Research has also been conducted on novel catalytic materials and their applications, e.g., integration of innovative amorphous alloy catalysts and magnetically stable bed reaction processes, novel chiral and heterogeneous chiral catalysts, adsorbents developed on the basis of spontaneous monolayer dispersion theory for separating and purifying $\mathrm{O}_{2}$ and CO, and various novel carbon materials etc. Significant progress has also been made in a number of engineering projects such as conversions of methanol to olefins and of coal to oil, industrialization of the production of rare-earth cis-1,4-polybutadiene rubber, and in catalysts for space and aviation applications etc. New characterization methods have also been developed, e.g., in-situ infrared spectroscopy, in-situ ultraviolet Raman spectroscopy, in-situ solid-state nuclear magnetic resonance spectroscopy, and deep ultraviolet and photoelectron spectroscopy etc. There has also been a substantial increase in the use of ultrahigh-resolution electron microscopy and quantum chemical calculations.

This special column has been compiled with the extensive support and help of colleagues in various catalytic fields. Because of limitations in our knowledge, there are inevitable omissions and defects. We would appreciate comments from experts and readers to enable us to rectify these.

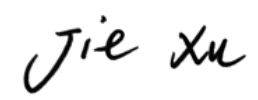

Jie Xu (徐杰)

Dalian National Laboratory for Clean Energy,

State Key Laboratory of Catalysis, Dalian Institute of Chemical Physics, Chinese Academy of Sciences, Dalian 116023, Liaoning, China E-mail address: xujie@dicp.ac.cn

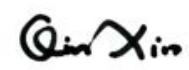

Qin Xin (辛勤)

State Key Laboratory of Catalysis, Dalian Institute of Chemical Physics, Chinese Academy of Sciences, Dalian 116023, Liaoning, China E-mail address: xinqin@dicp.ac.cn

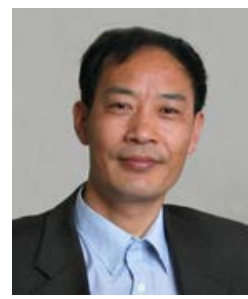

Professor Jie $\mathrm{Xu}$ is currently head of the division of biomass conversion and bio-energy, Dalian National Laboratory for Clean Energy. He received his B.S. and M.S. degrees from Zhengzhou University in 1981 and 1988, respectively. From 1994 to 1995, he worked at Truman University as a visiting scholar. In 1998, he obtained his Ph.D. degree from the Dalian Institute of Chemical Physics (DICP), 
CAS, and joined the DICP in the same year. He has been engaged in the synthesis of new catalytic materials and exploring new technologies for optimal use of resources. For example, he has developed novel organic, non-metal catalytic systems for hydrocarbon oxidation. In 2010, he won third prize in the Liaoning province award for technological innovation. He has chaired a number of programs, including the National High Technology Development Program, the National Natural Science Fund Key Program, and the National 11th Five-Year Technology-Based Plan, and 15 achievements have been evaluated. To date, he has published more than 200 SCI papers, one book, and 100 patents (45 authorized). He was approved to receive a State Council special allowance (2002), and has received CAS graduate school excellent teacher and CAS graduate school-Australian BHP Billiton tutor research awards (2006).

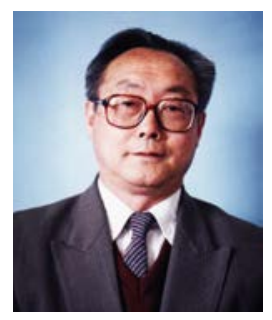

Professor Qin Xin has been working in the field of fundamental catalytic research for several decades. His main interests are the study of molecular adsorption states on catalyst surfaces, spectral characterization of catalysts, and the study of reaction kinetics. Since 1962, he has spent more than 30 years on the development of an in-situ Molecular Spectroscopy Laboratory. He has also gradually developed a series of in-situ characterization methods for catalytic studies, such as dual molecular probes. These methods have been adopted by more than 60 laboratories. His research activities have mainly been devoted to the following topics: (1) direct methanol fuel cells; (2) in-situ molecular spectroscopy in catalytic studies; (3) research on transition-metal nitrides and carbides; (4) characterization of oxo species in mixed oxide catalysts; and (5) investigations of HDS and HDN catalysts. He has presided over five cooperation programs, such as that between Louvain-la-Neuve Catholic University (Belgium) and the Dalian Institute of Chemical Physics, CAS. To date, he has published over 500 scientific papers and six books. Total citations to his work are 7700, with an average citation of 27, and an H-index of 46 from the Web of Science. He has been awarded the National and Chinese Academy of Sciences prize seven times.

\section{“中国催化三十年进展回顾” 专栏前言}

为纪念中国化学会成立八十周年, 中国化学会出版 了《高速发展的中国化学: 1982 2012》一书. 其中第二 十八章为催化部分. 三十年来, 我国的催化事业在基础 研究和应用成果转移转化方面取得了丰硕的成果, 主要 表现在: 一大批研究成果获得国内外各种奖项; 学术论 文数量和质量显著提高; 经济效益和社会效益明显; 形 成了诸多新的学科生长点并取得了重要进展; 人才队伍 数量和创新能力明显提升. 目前中国已发展成为名符其 实的催化大国, 在《高速发展的中国化学: 1982 2012》 一书中由于篇幅和时间的限制, 不能全面反映中国催化 的巨大进展, 在催化界同仁的建议和帮助下, 对其内容 进行了适当的补充并形成“中国催化三十年进展: 理论 和技术的创新”一文, 同时, 还邀请几位国内学者撰写 了综述, 组成“中国催化三十年进展回顾”专栏, 向读者 展示部分中国催化研究成果.

在催化领域, 人们将注意力集中在催化新材料、新 反应和新表征方法的开拓研究. 三十年来开拓的新催化 反应包括: 甲烷芳构化、水相反应条件下的费托合成、 纤维素和山梨醇裂解制乙二醇等. 同时, 人们开展了系 列催化新材料研究及应用研发, 例如: 非晶态合金催化 剂和磁稳定床反应工艺的创新与集成、新型手性和多相 手性催化剂、依据自发单层分散原理开发的氧气分离纯 化和一氧化碳分离纯化吸附剂、各种新型碳材料等. 并 获得了一批重大进展的工程项目, 如: 甲醇制烯烃、煤 制油、稀土顺丁橡胶产业化、用于航天航空的催化剂等. 在新表征方法研究方面, 在开拓普及原位红外光谱方法 的基础上开发了原位紫外拉曼光谱和原位固态核磁共 振谱, 开发建立了深紫外和光电子谱等, 在超高分辨分 析电镜和量化计算方面应用水平有了实质性的提升. 本专栏的完成得益于催化界同仁的大力支持和帮 助. 如有疏漏和欠妥之处, 恳请专家和读者指正. 